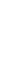

\title{
An Assessment of Social, Economic and Cultural Sustainability in the Management of Local Marine Conservation Area (KKLD) of Mayalibit Bay, Raja Ampat, West Papua, Indonesia
}

\author{
Handayani $^{1,3, *}$, Sutrisno Anggoro ${ }^{2}$, Boedi Hendrarto ${ }^{2}$, and Abdul Kohar ${ }^{2}$ \\ ${ }^{1}$ Doctoral Program of Environmental Science, School of Postgraduate Studies Diponegoro University, \\ Jl. Imam Bardjo, SH, Semarang, Indonesia \\ ${ }^{2}$ Faculty of Marine Sciences and Fisheries, Diponegoro University, Jl. Prof. Soedarto, Semarang, Indonesia \\ ${ }^{3}$ Polytechnic of Marine Sciences and Fisheries, Sorong, West Papua, Indonesia
}

\begin{abstract}
Marine conservation area is established to protect coastal and marine resources from water pollution, climate change, and over-exploitation. This research aimed to assess social, economic, and cultural sustainability, and fishermen individual characteristics as part of the fishery extension system in the management of local marine conservation area (KKLD) of Mayalibit Bay in Raja Ampat Regency, West Papua. Since the establishment of KKLD in Mayalibit Bay, patrols and monitoring activities have not been optimally performed. The area was purposively selected because the local marine conservation area of Mayalibit Bay is under the management the TPPKD with sea and terrestrial accessibilities from Waisai, the capital city of the regency. The research applied index evaluation and sustainability status data analysis using a Rap-FISHEXCOME technique. There were three major stages of data analysis: (1) determination of attributes of fishery extension dimensions; (2) evaluation of each attribute at an ordinal scale according to the sustainability criteria of each attribute; and (3) sustainability index ordination analysis using the MDS method. The social, economic, and cultural dimension indices with 10 attributes resulted in 53.57 sensitive attributes and the local fishermen personal characteristics with 14 attributes resulted in 64.84 sensitive attributes. These results proved a fairly sustainable status.
\end{abstract}

Keywords: KKLD of Mayalibit Bay, Local Marine Conservation, MDS, Rap-FISHEXCOME, Socio-Economic, Cultural Sustainability.

\section{INTRODUCTION}

The KKLD of Mayalibit Bay is part of Area II of the local is lets park (Taman Pulau-Pulau Kecil Daerah, later on TPPKD) of Raja Ampat. The 53.100-hectarebay is located in Waigeo Island, splitting the island into two parts with a narrow entrance, making it a relatively isolated area. Geographically, the Mayalibit Bay is located on the coordinates of $0^{\circ} 22^{\prime} 14^{\prime \prime}-0^{\circ} 05^{\prime} 00$ South, $130^{\circ} 36^{\prime} 43^{\prime \prime}-130^{\circ} 59^{\prime} 10^{\prime \prime}$ West. This water conservation area is the place where layered mangrove and segrass grow extensively. The establishment of the Mayalibit Bay and the other five areas as the local marine conservation areas in Raja Ampat Regency departed from intention and commitment of the local people to protecting coastal and marine resources biodiversity as their major income sources.

This research aimed to assess the management of the KKLD of Mayalibit Bay, Raja Ampat Regency, West Papua Province,

${ }^{*}$ Author to whom correspondence should be addressed.
Indonesia through an assessment of socio-economic and cultural sustainability of the local fishermen.

\section{RESEARCH METHOD}

This study applied a descriptive design with a mix method approach, in which both qualitative and quantitative methods were used. The research took place in the KKLD of Mayalibit Bay, Raja Ampat Regency, West Papua Province. The area was purposively selected because the local marine conservation area of Mayalibit Bay is under the management the TPPKD with sea and terrestrial accessibilities from Waisai Municipality, the capital city of Raja Ampat Regency. Villages for the research observation were also purposively selected owing to their status as either no take zone, restricted take or other zones in the KKLD of Mayalibit Bay, i.e., Yensner, Mumes, Warsambin, Lopintol, Kalitoko, Waifoy, and Kabilol. The research location map is provided in Figure 1. 


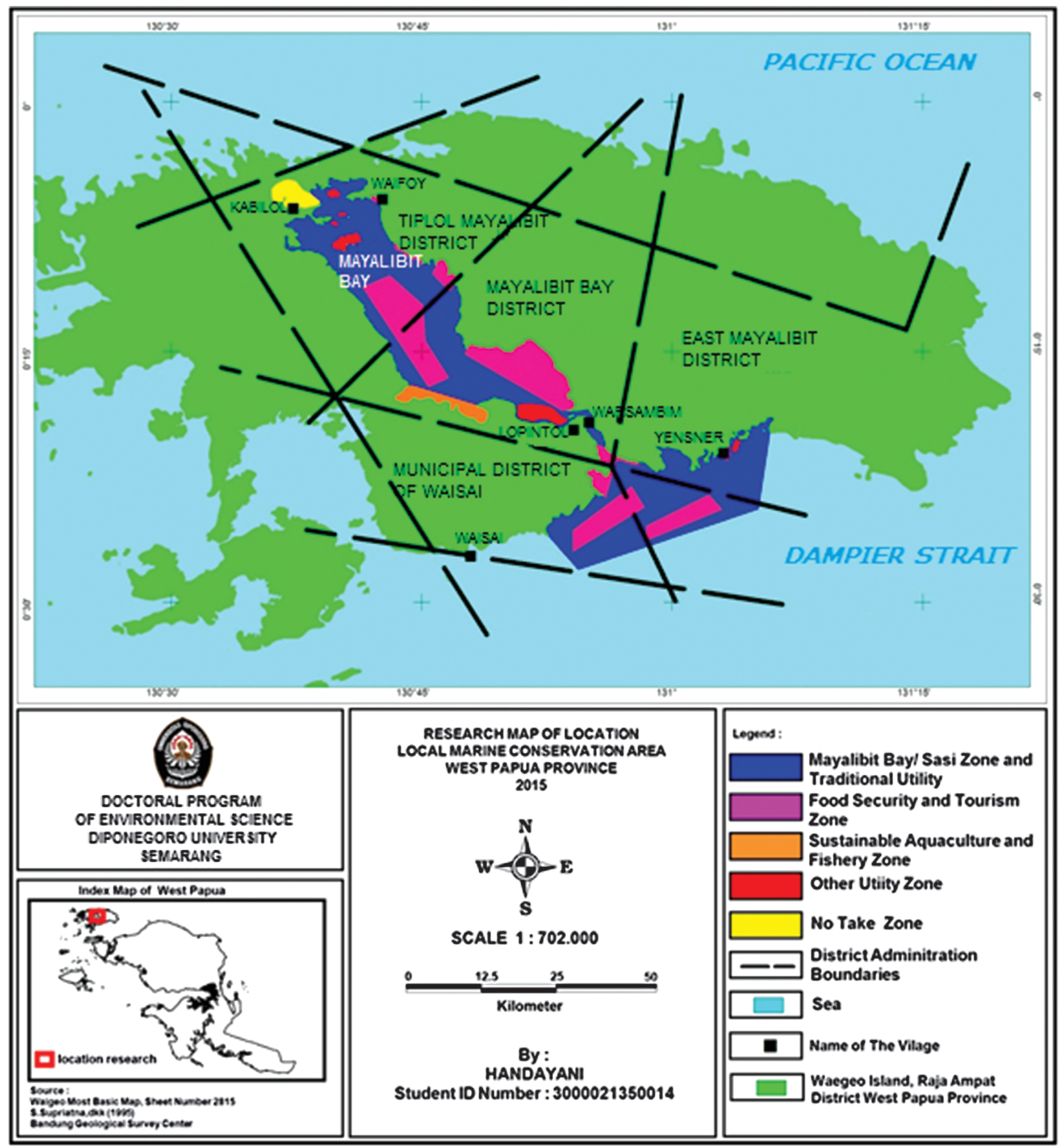

Fig. 1. Map of the research location.

The assessment of the social, economic and cultural sustainability and personal characteristics of the local fishermen used a Rap-FISHEXCOME technique, which was modified from Rapfish (Rapid Appraisal of Fisheries) with a multidimensional scaling. ${ }^{1}$ There were three major stages of data analysis:

(1) determination of attributes or criteria of the dimensions of fishery extension;

(2) evaluation of each attribute at an ordinal scale according to the sustainability criteria of each attribute; and

(3) ordination analysis stage of the sustainability indices using the MDS method. The sustainability indices can be categorized into bad (0-25), inadequate (26-50), fair (51-75), and good $(76-100) .^{2}$

\section{RESULTS AND DISCUSSION}

The multidimensional Rap-FISHEXCOME using a multidimensional scaling (MDS) ordination resulted in sustainable index for social, economic, and cultural dimensions of 53.57, or fairly sustainable, wheres the sustainable index for local fishermen personal characteristics resulted in 63.84 , or fairly sustainable. These sustainability indices were obtained according to the assessment of 26 attributes. Furthermore, the Rap-FISHEXCOME analysis of other sustainable index resulted in Stress and $R^{2}$ values. The Stress value for social, economic, and cultural dimensions was 0.1455 and for local fishermen personal characteristics was 0.1403 . These figures were less than 0.25 , meaning that the analysis outputs were quite good. The $\mathrm{R}^{2}$ (determination coefficient) value showed a correlation between the systems and the attributes in use. The $\mathrm{R}^{2}$ value for social, economic, and cultural dimensions was 0.9444 , whereas that of for local fishermen personal characteristics was 0.9432 . these figures denoted that the attributes in use for the weighted indicators were capable of explaining the implementation of the governance of the fishery extension and community systems at $95.03 \%$. Therefore, all of the attributes in use were quite good.

A cluster-based leverage analysis by distance resulted in two clusters (cluster 1 with RMS 2.60-1.25; and cluster 2 with RMS $1.02-0.15)$. The six highest RMS value attributes were education level (2.60), fossil fuel/market accessibility (1.91), media accessibility (1.83), diversification of fishery products (1.82), respect to local wisdom (1.25), and fishermen income (1.02). 
Education is a fundamental instrument for human capital development and socio-economic development by which the whole policies on the human resource development are implemented. ${ }^{3}$ Local communities who lived in three districts inside the KKLD of Mayalibit Bay mostly had inadequate education since they were only elementary school graduates.

Traditionally, the fishermen did their fishing activity nearby their own homes because of lacking boats with larger capacity and unaffordable operational cost to buy the fossil fuel or ice cube. "One day fishing" habit with traditional fishing gears and boats in close range fishing ground contributed to the fishermen income in the research location. ${ }^{4}$

The results of the leverage analysis of local fishermen personal characteristics were divided into two clusters: cluster 1 with RMS of 2.80-1.61; and cluster 2 with RMS of 0.96-0.10). Five attributes with the highest RMS rates were as follows:

(1) local fishermen perception towards extension method (2.80);

(2) local fishermen perception towards extension materials;

(3) local fishermen participation in the activities (2.03);

(4) attitudes towards fishery extension (1.91); and

(5) local fishermen expectation to the KKLD (1.61)

Participation is defined as individual, group and organizational process to take part actively in decision-making that affects them. ${ }^{5-8}$ The high participation rate of the local people in the extension proved to enhance commitment to the extension program. ${ }^{9}$

Attitude factor deals with to what extent mentality and readiness of an individual to react the object in particular environment as one of appreciation of the object, such as the extension in the current research. Attitude can be defined as a form of evaluative statement, either exciting or annoying, of object, individual, or event. ${ }^{10}$ The research observation documented $55.02 \%$ of the local fishermen with positive responses and $44.99 \%$ of the fishermen with extremely positives responses to the extension program in their villages. The mental attitudes of the fishermen towards the use of environmental-friendly technologies for catching the fishes for the environmental conservation in the KKLD of Mayalibit Bay resulted in 55.39\% with positive responses and $44.61 \%$ of the respondents with extremely positive shows. The positive attitude of the local fishermen towards the provision of the extension and environmental preservation had to be maintained to support other attributes as well as to support the environmental management of the KKLD of Mayalibit Bay. The similar research reports that attitude/behavior are those of influential factors with a direct impact on the change in behaviors of the local fishermen. ${ }^{11}$

The above results proved that the local fishermen had positive expectations towards the establishment of the conservation area in their respective regency. A conservation area was believed to help control fishing activities using fishing gears, which threatened fish resource ecosystem. Once the ecosystem degradation had occured, catches volume for the local fishermen changed. Positive expectations also revealed among the local fishermen towards the presence of the extension staff around them to guide and, particularly, to bridge the market as the local fishermen had too often confronted with problems due to limited market access.

\section{CONCLUSION}

Sustainability indices of social, economic, and culture as well as local fishermen personal characteristics were at the status of adequately sustainable. To improve this sutainability status towards the management of the KKLD of Mayalibit Bay, it is necessary to optimize education, fossil fuel/market accessibility, media accessibility, diversification of fishery products, and respect to local wisdom. Furthermore, the research perceived it necessary to improve the local fishermen perceptions towards extension methods and materials and participation and attitudes of the local fishermen to the fishery extension activities.

Acknowledgment: This study is part of the author's dissertation: "Priority of Policy on Fishery Extension in Environmental Management of Local Marine Conservation Area (KKLD) of Mayalibit Bay, West Papua Province." The authors would like to pay their gratitudes to Adri Kaiba, M. Si. (Head of UPTD KKLD Kabupaten Raja Ampat), Kresia Mambrasar, S. Pi.; Yansen Mentasan; Dortheus Ansan; Nico Rumbino; Isak Ansan and Hosea Dalam (field staff of KKLD Mayalibit Bay) and all fishermen who took part into this research. The authors are also indebted to Albert Nebore (CI Papua Leader), Nur Ismuh Hidayat, S. Kl. (CIstaff), colleagues in The Nature Conservancy (TNC) for the information about KKLD Mayalibit Bay of Raja Ampat Regency, and Widodo for editing.

\section{References and Notes}

1. P. Kavanagh, University of British Columbia, Fisheries Centre 68 (2001).

2. S. B. Susilo, Program Pasca Sarjana Institut Pertanian Bogor 56-58 (2003).

3. R. Atalaya, Procedia-Social and Behavioral Sciences 174, 969 (2015).

4. Handayani, Program Pascasarjana Universitas Diponegoro Semarang 34-35 (2008)

5. International Institute of Rural Reconstruction, Intl. Inst. of Rural. Recons. 78 (1988).

6. S. Jentoft and B. McCay, Marine Policy 19, 227 (1995).

7. G. Rowe and L. Frewer, Technology and Human Values 25, 3 (2000).

8. A. Wandersman, Journal of Applied Behavioural Science 17, 27 (1981)

9. H. F. Lionberger and H. C. Chang, Extension Education and Rural Program (1981).

10. S. P. Robbins and T. A. Judge, Salemba Empat 45-48 (2008)

11. P. Sanjatmiko, Institut Pertanian Bogor 68-70 (2011). 